「我が社の技術革新」特集

\title{
近代防水を超えて 一田島ルーフィング株式会社一
}

\section{1. はじめに}

ビル建築に抒ける屋根の役割で, 最も重要なものの一 つに防水機能があげられる。超高層ビルの眼下に無数に 広がるコンクリートの屋根, 屋根, 屋根。その一つ一つ に防水層が施されているのを御存知だろうか。

防水層は，シート状の防水材料である「アスファルト ルーフィング」を数枚積層させて形成される。

本稿では創立70年の歴史を背景に, ルーフィングメー カーとしての技術的変革と発展, さらには近代防水を超 えた末来への指向について御紹介したい。

\section{2. 建築技術の発達と高度化するニーズ}

アスファルトルーフィングの基本構成は図」に示され る。中央の基材にアスファルトを含浸させ，さらにその 上下面にアスファルトを菬覆したものである。従って， ルーフィングとしての性能はこの両者の品質に負う処が 大きい。特に機械的性能については，基材の特性そのも のが直接の影響として現われる。

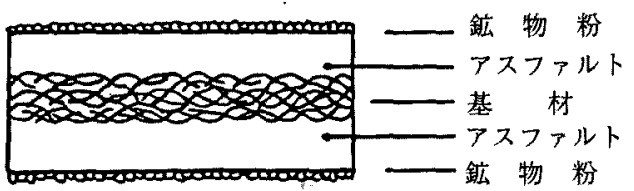

図1 アスファルトルーフィング

大正 8 年, 初の国産化に成功して以来，ルーフィンク の製造が本格的な採用の波に乘ったのは昭和の初期であ った。当時使用されていた基材は，厚手の多孔質紙や石 綿紙である。

ところが，戦後復興期に入り鉄筋コンクリート造の建 築が増加するに伴い，屋根からの漏水が多発し問題とな った。この原因は，打設コンクリートの硬化過程に生じ る表面の収縮亀裂にルーフィングが追従できす破断した ためであった。

さらに，その後の建築技術の発達は目覚ましく，高層 化の流れの中で柔構造が普及し始めた。この構造(鉄骨 造)は耐震を目的に外力を采軟な動きとして皘極的に許
容するむのであり，従来では考えられなかった大きなる す方交生じる。

このように多様に変革する建筑のニーズは，従来の触 を基材としたルーフィングを不満とし，より强勒で，よ り延伸性に富んだルーフィングを求めるようになった。

\section{3.『不識布ルーフィング」の開発}

高強度, 高延伸性ルーフィングの開発のポイントは基 材の革新にあった。これらの要求を満たす基材の形態と して着目したのが不織布である。素材䄉維としてサイザ ル麻，マニラ麻がスタートの検討対象となった。天然接 維の不織布である。この結果は，延伸性は向上したもの の, 耐久性, 加工性に問題が残った。

次に，素材䢂維の見直しから，合成織維のビニロンか 候補として浮.上し，ルーフィング基材の要求特性を盛り 込んだビニロン不織布の品質設定と加工方法の検討か滩 められた。要求特性は次の三点である。(1)必要强度と延 伸性を有すること。(2)機械的特性に著しい方向性を生し ないこと。(3)アスファルトの含浸を考虑しポーラスで蒿 高であること。

昭和 36 年鋭意研究の結果, 䄉維長 $10 \mathrm{~cm}$ 以上のビ二口 ン長䄉維を空気流によりランダムに，かつ均一厚のウェ ブに形成する乾式不織布の生産に成功した。当時として は面期的なことであった。具体的製造方法は次の通り。

図 2 に示すように，非捲縮の長縺維からなるスライハ -2を挾持ロール3で送り出し, 高速回転する植針口一 ル4でさばき，すきけずりつつ，植針ロールの回転によ り生じる風圧と，別に循還する気流10の作用で分離・我

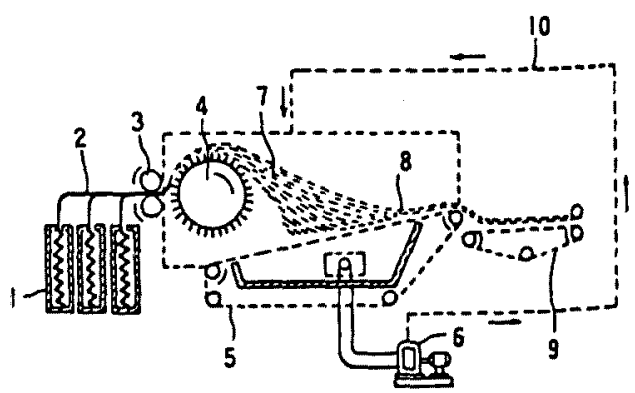

图 2 不織布製造装置 
散させ，定速で移行するコンベア 5 上に堆積させて，方 向性を持たない繊維ウェプ 8 を形成しこれに適宜，バ インダーを含浸硬化させて不織布を得る。

こうして得られた不織布に, 従来の紙では不可能であ った高品質のアスファルトを含浸・塗覆し, 表面に鉱物 粉粒を撤着させて「不織布ルーフィング」が製造され る。

この不織布と不織布ルーフィングについては各々, 構 造と製造法に関する特許を取得し, 海外人は技術輸出の 形で飛躍を計ることができた。又，国内では防水材料の 主流の地位を占めるに到り, 昭和52年にJIS A6022「ス トレッチルーフィング」として制定された。以後，建設 省を始めとする官公庁仕様の指定を受け，汎用化される ようになった。

我が国の近代防水は，この「不織布ルーフィング」に おいて確立したといっても過言ではない。

\section{4. 冷工法『ガムロン」の出現と市場の広がり}

不織布ルーフィンダを核としたアスファルト防水の発 展は, ルーフィングの施工法の改革を焦点としてひきつ がれた。従来の工法は, 加熱溶融させた液状アスファル 卜を現場で流しながらルーフィングを貼り重ねてゆく方 法で，一般的に「熱工法」と呼ばれる。

熱工法は水密性(防水性)に絶大な信頼を得ている反 面, 溶融アスファルトに起因する煙や作業員の火傷等, 作業環境上の問題をはらんでいる。

アスファルト防水の良さを確保しつつ, これらの問題 の解決を画ったのが自己接着型防水材「ガムロン』であ る。この製品を用いる工法は溶融アスファルトを全く必 要としないことから「冷工法」と呼ばれる。

「ガムロン」の構成を図 3 に示す。不織布ルーフィン クの下面，もしくは上下両面に特殊ゴムアスの粘着層を 配し，表面を剝離紙で被覆したものである。施工の際 は，この剝離紙を取り除き，粘着面を被着体へ押しあて るだけでよい。

1974年のブライトン国際シンポジウムでの発表は, 大 きな反響を呼び，国内よりむしろ海外での高い評価が先

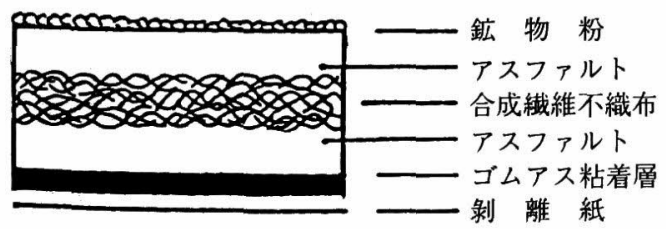

図3ガムロン

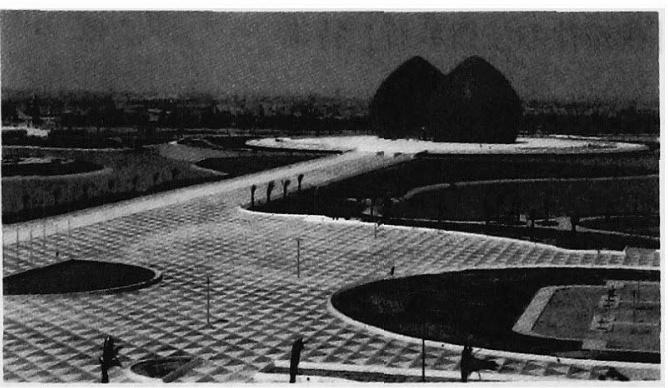

図 4 THE MONUMENT OF SADDAM'S QADISSIYA MARTYRS (IRAQ)

行した。以後海外工事ではガムロンの採用が増加するこ ととなる。

工法の改革に伴い，ガムロンが果たした大きな功績は 市場分野の広がりを可能にしたことである。従来の熱工 法では不可能とされた大規模垂直壁, 急勾配斜面等への 対応が実現化し，土木分野の本格防水を確立するに至っ た。具体的には, 地下構築物 (図 4 地下は広大な博物館 となっている)，海底沈埋管、トンネル等をあげること ができる。いずれも海外での数多くの実績が自信と信頼 を高めてくれている。

『ガムロン」は，市場の広がりと同時に夢の広がりを 与えてくれる製品である。

\section{5. 屋上機能の開発を目指して}

建築物の意図する処は，構造体それ自身にはなく，そ こから生まれ出る空間にある。近年の都市集中化は，建 築物個々のテリトリーを超越し, 街として, 都市として の空間創造を重要テーマとしている。

防水も建築機能の重要な一要素である以上，防水機能 と高度な付加機能との複合開発により，斬新な空間創造 を可能にすることができる。

既に断熱材と防水層との複合化技術は，空間環境の向 上システムとして幅広く提供されている。

又, 従来の勾配屋根仕上げ材としての『シングル」に 加えて，セラミックス，金属等の素材の展開による意匠 重視のシステムも実用化の段階に入った。

さらに，積極的な空間創造の観点から，都心の屋上に も小鳥のさえずりをイメージした，「屋上緑化システ ム」の構築ももう目前にある。

屋根は正に天と地の接点である。常に広い視野をもち つつ, 確固たる防水技術を礎に，一歩一歩着実に我が社 の夢を未来の空に描いていこうと思う。 